\title{
Malaysia - OIC Imports: Patterns, Determinants, and Prospects
}

\author{
Irwan Shah Zainal Abidin ${ }^{1}$, Nurulhuda Mohd Satar ${ }^{2}$, Mohd Dan Jantan ${ }^{1} \&$ Muhammad Haseeb ${ }^{1}$ \\ ${ }^{1}$ Department of Economics, School of Economics, Banking and Finance, Universiti Utara Malaysia (UUM), \\ Sintok, Malaysia \\ ${ }^{2}$ Department of Economics, Faculty of Economics and Administration, University of Malaya (UM), Malaysia \\ Correspondence: Muhammad Haseeb, Department of Economics, School of Economics, Banking and Finance, \\ Universiti Utara Malaysia (UUM) Sintok 06010 Kedah, Malaysia. E-mail: scholar_economist@yahoo.co.uk
}

Received: June 24, 2015 Accepted: July 21, 2015 Online Published: September 27, 2015

doi:10.5539/jsd.v8n8p100 URL: http://dx.doi.org/10.5539/jsd.v8n8p100

\begin{abstract}
The ultimate objective of this study to empirically investigate the import relations between Malaysia and OIC countries. The annual time series data from 1995 to 2012 have been utilized. The results of gravity model shows that real exchange rate of Malaysia and other OIC countries has a positive and significant effect on Malaysia-OIC import. Whereas, CPI of Malaysia and per capita GDP of other OIC countries shows a negative relationship with import volumes of Malaysia from -OIC countries. We also found the evidence of the role of quality of institutions in enhancing Malaysia-OIC import relationship. These findings are important especially for policy makers in crafting policies to improve Malaysia-OIC import relationship in the future. In line with the empirical findings, it is crucial for Malaysian government to focus on accelerating the efforts to establish the Islamic Common Market (ICM), liberalizing the economy, further improving the strategic sectors such as the Islamic Banking and Finance, and intensify endeavors in curbing corrupt practice.
\end{abstract}

Keywords: Malaysia, OIC, gravity model, import

\section{Introduction}

International trade has always been playing a crucial role in the process of growth and development in Malaysia, especially in transforming the economy from a low income to upper-middle income category. Traditionally, Malaysia's major trading partners were the United States of America, The European Union (EU), and Japan. But this trend has been shifted somewhat primarily due to the 2008/09 world economic and financial crises. In 2009 for example, Malaysia's major exporting and importing nations have tilted more towards other new markets and non-traditional countries such as China (MITI, 2010). In response to the crises, the Malaysian government, under the New Economic Model (NEM), has embarked on a new strategy to shift its trade dependency on the traditional markets and exploring new markets for exports and imports. Under NEM, one of the markets being targeted is the Middle Eastern countries.

Considering that the OIC member countries have more than 60 per cent of vital resources and with 1.6 billion of the world's population, this general picture of the state of OIC trade performance can be deemed as weak. Furthermore, in light of the present economic and financial crises, there is a need for Malaysia to shift its imports destinations away from its traditional trading partners, and one of these destinations is the OIC region. Although there are many factors responsible for the weaknesses of this trade relation, the leaders and the people of the OIC countries believe that there are many fields and opportunities for growth of mutual trade relations. It is therefore crucial to examine and analyze the on-going Malaysia-OIC imports relationship in this context. The objectives of this study are:

1) To examine the pattern of imports between Malaysia and the OIC member countries.

2) To identify the determinants of Malaysia's imports from the OIC member countries.

3) To provide policy recommendations to improve Malaysia-OIC trade relationship.

This research focuses on import relations between Malaysia and the OIC member countries and will address the subsequent research questions:-

1) What are the pattern of imports between Malaysia and the OIC member countries? 
2) What are the determinants of Malaysia's import to the OIC member countries?

3) What would be the future prospects of imports relations between Malaysia and the OIC member countries?

The focus of this research is to examine imports relationship between Malaysia and the OIC member countries. In the post-September 11 world and in light with the economic and financial crises, there is a need for Malaysia to shift its trade destinations away from its traditional trading partners, and one of this destination is in the OIC region. For the OIC member countries as a whole, they are still trade more with the outside world than among themselves (Kabir, 1998). In analyzing the determinants of imports using gravity model, this research will provide political economic dimensions to the analysis, which is by incorporating the role of institutions into the gravity equations.

Applying a gravity model using panel data will provide a new perspective to the OIC trade literature as most studies were done by using the revealed comparative advantage (RCA), trade intensity index, or the multivariate technique based on the discriminant analysis method. From geographical aspect, this study will focus on Malaysia and the rest of the OIC member countries, unlike previous studies where most of them focusing more on the intra-OIC trade and a sub-group of the OIC countries, such as the Gulf Cooperation Council (GCC). This study will eventually provide some policy analysis and eventually developing policy recommendations in an effort to enhance trade relationship between Malaysia and the OIC member countries in the near future.

\subsection{Malaysia-OIC: An Overview of Trade Relationship}

Over the recent years, Malaysia-OIC trade relationship is relatively small compared with Malaysia's trade with the rest of the world although it has shown an increasing pattern. In 2012 for example, Malaysia's total trade with the OIC member countries accounted only 7.47 per cent of its total global trade (IMF and Dinar Standard, 2012). The detail can be seen in Figure 1.

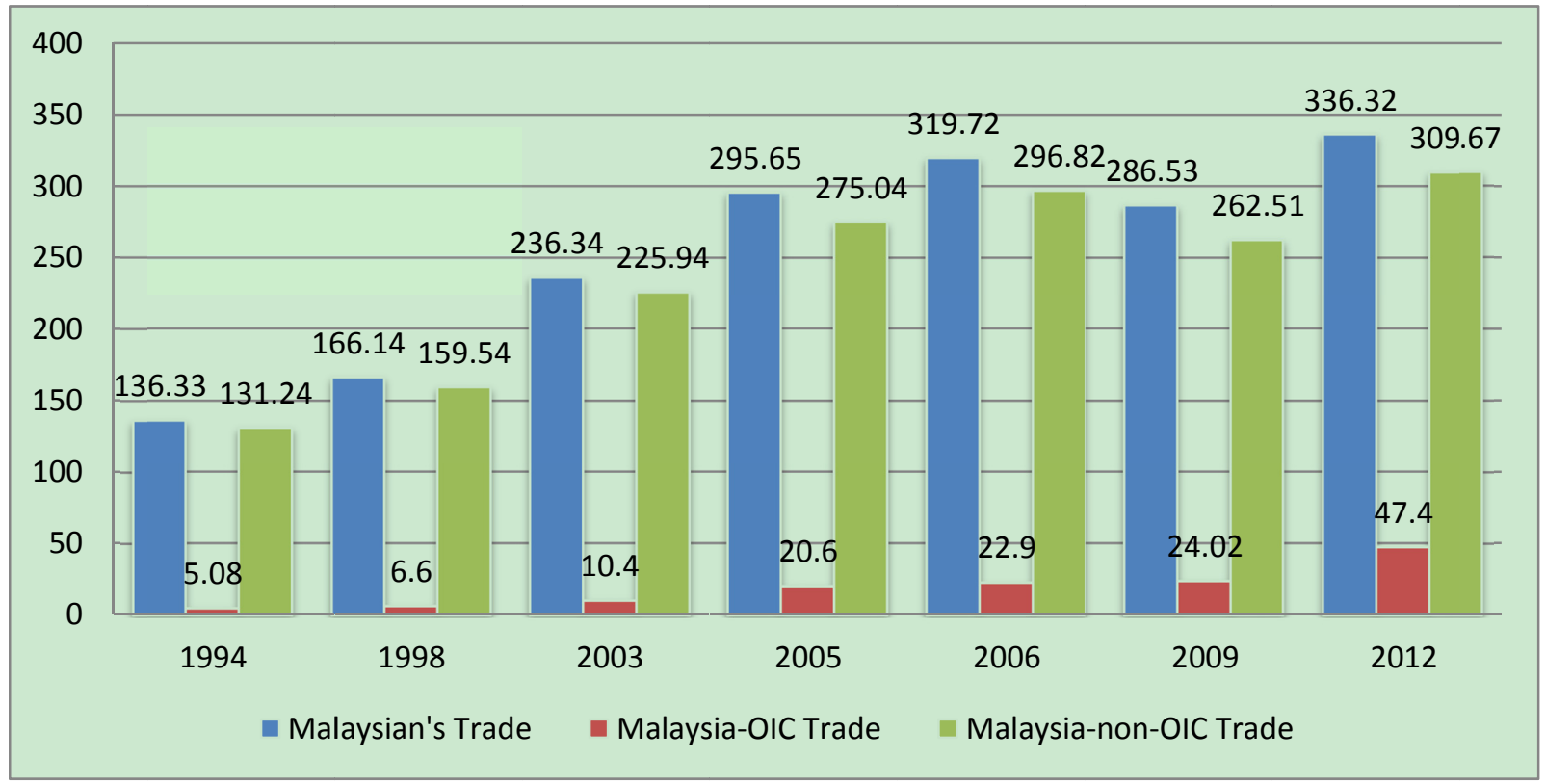

Figure 1. Malaysia-OIC trade for the year 1994, 1998, 2003, 2005, 2006, 2009 and 2012

Source: http://www.carsicm.ir/icmroot/public/Statistics/OIC-View.htm. Retrieved on 29 September 2013.

Overall, Malaysia's trade with the OIC member countries for the years 1998, 2003, 2009, and 2012 are USD6.6 billion, USD10.4 billion, USD24.02 billion, and USD47.4 billion respectively. On the other hand, Malaysia's trade with non-OIC countries amounted at USD159.54 billion, USD225.94 billion, USD262.51 billion, and USD309.67 billion respectively for the years 1998, 2003, 2009, and 2012. Considering that the OIC countries have more than 60 per cent of vital resources and with 1.3 billion or one-sixth of the world's population, this general picture of the state of OIC trade performance can be deemed as weak. Although there are many factors responsible for the weaknesses of this trade relation, the leaders and the people of the OIC countries believe that there are many fields and opportunities for growth of mutual trade relations. 
Table 1, on the other hand, provides data on Malaysia's imports from selected individual OIC countries for selected years of 1997, 1999, 2001, 2003, 2006, 2009 and 2012 respectively.

Table 1. Malaysia's imports from individual OIC member countries, selected years and countries (USD in Million)

\begin{tabular}{|c|c|c|c|c|c|c|c|}
\hline $\begin{array}{l}\text { Year/ } \\
\text { Country }\end{array}$ & 1997 & 1999 & 2001 & 2003 & 2006 & 2009 & 2012 \\
\hline Indonesia & 1464.0 & 1756.64 & 2241.38 & 2939.01 & 4951.79 & 6558.22 & 10088.1 \\
\hline Saudi Arabia & 360.2 & 287.47 & 636.49 & 583.13 & 2329.78 & 1107.85 & 2454.68 \\
\hline U.A.E. & 103.54 & 116.62 & 163.84 & 299.77 & 968.93 & 1741.07 & 4017.22 \\
\hline Pakistan & 40.18 & 47.04 & 43.88 & 45.1 & 59.35 & 150.37 & 252.26 \\
\hline Turkey & 176.94 & 48.86 & 42.98 & 43.33 & 62.88 & 113.3 & 202.62 \\
\hline Brunei & 24.65 & 12.03 & 5.05 & 31.72 & 75.53 & 67.84 & 52.58 \\
\hline Iran & 32.14 & 48.41 & 149.13 & 100.15 & 581.21 & 324.54 & 341.45 \\
\hline Qatar & 19.58 & 18.68 & 47.64 & 14.12 & 79.71 & 331.23 & 1342.66 \\
\hline Bangladesh & 10.53 & 7.26 & 15.28 & 15.05 & 22.81 & 21.72 & 74.84 \\
\hline Egypt & 9.49 & 12.86 & 9.85 & 23.26 & 48.94 & 36.33 & 177.72 \\
\hline Jordan & 31.64 & 35.42 & 25.03 & 29.71 & 58.3 & 24.47 & 59.15 \\
\hline Yemen & 0.01 & 0.04 & 295.25 & 212.15 & 52.08 & 73.66 & 8.58 \\
\hline
\end{tabular}

Based on Table 1, it seems that in the year of 1997, 1999, 2001, 2003, 2006, 2009 and 2012 Malaysia's major importing country in the OIC is Indonesia. In 2012, Malaysia's top six importing countries are Indonesia, Saudi Arabia, U.A.E., Qatar, Iran and Pakistan with the value of imports of USD10088.1 million, USD4017.22 million, USD2454.68 million, USD1342.66 million, USD341.45 and USD252.26 million correspondingly. In 2009, Malaysia's imports to Indonesia amounted of 55 per cent of Malaysia's total import value to the OIC for that year. In 1997, Malaysia's imports from Indonesia accounted for USD1,464.09 million or around 60 per cent of total import value for the year observed.

\section{Literature Review}

The gravity model was first applied to international trade studies by Tinbergen (1962) and Poyhonen (1963) to analyze the patterns of bilateral trade flows among the European countries. The model is based on the analogy of Newton's law of gravity which states that the bilateral trade flows between two countries is proportional to its Gross Domestic Product (GDP) as a proxy of size and diminishes with distance, other things being equal (Krugman \& Obstfeld, 2009).

Later, the model has been augmented to take into account other factors in explaining trade flows among countries. Frankel et al. (1995) for instance, added dummy variables in the model for common border and language. Other researchers have included non-economic variables, such as political and institutional variables into the extended gravity model. Such studies are conducted by Summary (1989), Dollar and Kraay (2002), Levchenko (2004), and Anderson and Marcoullier (2002). They found positive relationship between bilateral trade flows and the political and institutional qualities.

Asmak and Abu-Hussin (2009) analyzed Malaysia's trade relations with the Gulf Cooperation Council (GCC) countries which consist of the United Arab Emirates (UAE), Bahrain, Saudi Arabia, Oman, Qatar, and Kuwait. Using trade intensity index, they showed that Malaysia's trade with the individual GCC country and with GCC as a group were very low during the $1990-2007$ period of study. They provided suggestions on how to improve Malaysia-GCC trade relations in the future such as to expedite the Free Trade Agreement (FTA) initiative, and focusing on niche areas which they have comparative advantage at such as Halal Food services, Islamic Banking and Finance services, tourism sector, Bio-fuel industries, constructions, education sector, and petrochemical industries. 
Endoh (1999) employed population variable in the model, which has a negative effects on trade flows. Frankel et al. (1995) and Elliott and Ikemoto (2004) introduced per capita income as a proxy to the level of development in explaining international trade. Filippini (2003) pointed out that there are two aspect worth mentioning when using gravity model, that is, the concepts of distance and mass ought to be reinterpreted according to the social and economic phenomenon under scrutiny and the multiplicative formulation of the law was generally kept even if an additive one might have seemed to be as good as the other.

Ismail (2008), on the other hand, examined the pattern of trade between Malaysia and eighty trading partners, where twenty of which are OIC members. In his research, he found that Malaysia trade with countries which have similar in terms of size but different in terms of factor endowment. Balassa (1961) showed that as the economic integration increases, trade barriers or forms of protectionism, such as tariffs, non-tariff restrictions, import quotas, government regulations, etc., would decrease. Studies specifically addressed on the issue of the establishment of the Islamic Common Market (ICM) as a long term goal for OIC are still scarce (Amin and Hamid, 2009). But there are some studies which supported the establishment of the ICM. Shalaby (1988), Anjum (1996), Ariff (1998), Ahmad and Ugurel (1998), Dabour (2004), and Amin and Hamid (2009) are among them.

Hassan (2002) proposed that the establishment of the Islamic Common Market (ICM) is a step in the right direction and the way forward for the OIC member countries to enhance their trade relationship in the long term. Amin and Hamid (2009) showed that the OIC is now heading in the right direction as far as the establishment of the ICM is concerned. But they warned that the major impediment for the materialization of the ICM was a lack of political commitment among the member countries.

\section{Methodology}

\subsection{The Gravity Model}

A) Brief Statement

The Gravity model initiate with setting out the traditional gravity model and nothing clues to uniting it with economic theory. The gravity model of world trade illustrate on parallel with Newton's Law of universal gravitation. The Newton's gravity model is stated that the magnetism between two objects in the universe is directly proportional to the product of their size and inversely proportional to the distance between them. By analogy, gravity model explained that a mass production supplied at one origin is attracted to a mass of demand from the other origin, but the high flow is reduced by distance between them. Strictly applying the analogy,

$$
N_{i j}=C \frac{M_{i} M_{j}}{D_{i j}}
$$

where $\mathrm{N}_{i j}$ is imports of country $i$ from country $j, \mathrm{C}$ is gravitational constant, $\mathrm{M}_{\mathrm{i}}$ is economic mass of country $i$ and $\mathrm{M}_{\mathrm{j}}$ is economic mass of country $j . \mathrm{D}_{i j}$ is the distance between capital of country $i$ to capital of country $j$. The natural- $\log$ form of the above model is stated in Equation 2

$$
\ln N_{i j}=\phi+\alpha \ln M_{i}+\beta \ln M_{j}-\lambda \ln D_{i j}+\varepsilon_{i j}
$$

The current form of model countenance extreme criticism from Anderson and Van Wincoop (2003), in this case we have to develop an alternative form of model that they favour in firm microeconomic foundation.

B) A derivation

There are some assumptions which we have follow before derive alternative model.

1) There is no interference in trade.

2) The worldwide households do have homothetic and identical utility functions.

3) All the countries concentrate in the production of possible and different varieties of goods. Everywhere the required basket of goods must be same. Small economy produces smaller quantity of goods. For example country $i$ produce $\mathrm{J}_{\mathrm{i}}$ different varieties in over the world composed of $\mathrm{N}$ countries so that $J=\sum_{i=1}^{N} J_{i}$. Furthermore, $\mathrm{P}$ is price and $\mathrm{V}$ is variety in term the numeraire and $\mathrm{T}_{\mathrm{i}, \mathrm{v}}$ is a production of country $i$ of variety v. It can be express below; 


$$
M_{i}=\sum_{v=1}^{J i} P_{v} \cdot T_{i, v} . \text { Further, } M_{w}=\sum_{v=1}^{J} P_{v} \cdot T_{i, v}=\sum_{I=1}^{N} M_{i}
$$

Note: $\mathrm{i}$ is a country index, while $\mathrm{v}$ is a variety index.

C) The CES case:

$$
F_{i}=\sum^{N} \beta_{j}^{1 / \theta} G_{i j}{ }^{\theta-1 / \theta}
$$

where $\mathrm{G}_{\mathrm{ij}}$ is consumption of country $\mathrm{i}$ and $\beta_{j}$ worlat ${ }^{1}$ output percentage produced by country $\mathrm{j}$ :

$$
\beta_{j}=M_{j} / M_{w}
$$

There is a balance trade among all countries in the aggregate.

There is an additional assumption showing that country $\mathrm{j}$ sell all variety at equal price: $P_{v, i j}=P_{v, j}=P_{i j}$. It is assumed that there is no price difference or price discrimination, as buyer shows $(P v, i j)=P v, j)$ and furthermore, there is no difference exists in home price in case of variety as well $(P v, i j)=P i j)$. Given $\mathrm{M}_{\mathrm{i}}$, the solution is:

$$
G_{i j}=\beta_{j}(P i j / P i)^{-\theta} \frac{M_{i}}{P_{i}} \text { where } P_{i}=\left(\sum_{j=1}^{J}\left(\beta_{j} P_{i j}{ }^{1-\theta}\right)\right)^{1 / 1-\theta}
$$

This shows that i's preferred consumption of all variety produced by country $\mathrm{j}$. Imports $\mathrm{N}_{\mathrm{ij}}$ of country $\mathrm{i}$ from country j equal $\mathrm{P}_{\mathrm{ij}} \mathrm{G}_{\mathrm{ij}}$. Thus,

$$
N_{i j}=\beta_{j}\left(\frac{P_{i j}}{P_{i}}\right)^{1-\theta} \text { and } M_{i}=\left(\frac{P_{i j}}{P_{i}}\right)^{1-\theta} \frac{M_{i} M_{j}}{M_{w}}
$$

By the same interpretation

$$
N_{j i}=\beta_{j}\left(\frac{P_{j i}}{P_{j}}\right)^{1-\theta} \text { and } M_{j}=\left(\frac{P_{j i}}{P_{j}}\right)^{1-\theta} \frac{M_{j} M_{i}}{M_{w}}
$$

It is noted that study not assumed that $\mathrm{N}_{\mathrm{ij}}=\mathrm{N}_{\mathrm{ji}}$, meaning that there is balance bilateral trade. The balance bilateral trade possible if and only if $1=\theta$ than study would have

$$
\left(\frac{P_{i j}}{P_{i}}\right)^{1-\theta}=\left(\frac{P_{j i}}{P_{j}}\right)^{1-\theta}=1 .
$$

But such balanced trade will follow independently under subsequent assumptions (AvW).

It is assumed that there are frictions of all sorts in foreign trade. From $P_{i j}$ and $P_{i}, P_{i j}$ is higher and $P_{i j}=t_{i j} P_{j}$ where $t_{i j}=1+C(C=$ trade cost $)$. From $P_{i j}=t_{i j} P_{j}$ study can explain that:

$$
N i j=\left(\frac{t i_{j} P_{j}}{P_{i}}\right)^{1-\theta} \frac{M_{i} M_{j}}{M_{w}}
$$

This is the basic gravity equation. Further, if we talk about Anderson-Van Wincoop Specification, it is start from

$$
F_{i}=\sum_{j=1}^{N} N_{j} G_{i j}{ }^{\theta-1 / \theta}
$$

where $\mathrm{N}_{\mathrm{j}}$ is the different varieties produced by country $\mathrm{j}$ and for single variety: 


$$
G i j=\left(\frac{P_{i j}}{P_{i}}\right)^{-\theta} \frac{M_{i}}{P_{i}}
$$

where

$$
P_{i}=\left(\sum_{j=1}^{J}\left(N_{j} P_{i j}^{1-\theta}\right)\right)^{1-\theta}
$$

so, total import from country $\mathrm{j}, \mathrm{N}_{\mathrm{ij}}$ is equal

$\mathrm{N}_{\mathrm{ij}}=\mathrm{N}_{\mathrm{j}} \mathrm{P}_{\mathrm{ij}} \mathrm{G}_{\mathrm{ij}}$ Thus

$$
N_{i j}=N_{J}\left(\frac{P_{i j}}{P_{i}}\right) \text { and } M_{i}=N_{J}\left(\frac{t_{i j} P_{j}}{P_{i}}\right)^{1-\theta} M_{i}
$$

From the starting it is assumed that $\mathrm{P}_{\mathrm{j}}$ is the same despite of variety $\mathrm{v}$ and it is also assumed that the balance trade of each country in the aggregate. Let $\mathrm{t}_{\mathrm{ij}}=\mathrm{t}_{\mathrm{ji}}$ than we can prove that $\mathrm{Pj}$ simply as:

$$
P j=\left(\frac{M_{j}}{M_{w} N_{j}}\right)^{\frac{1}{1-\theta}} \frac{1}{P_{j}} \operatorname{orP}_{j}^{1-\theta}=\left(\frac{M_{j}}{M_{w} N_{j}}\right)\left(\frac{1}{P_{j}}\right)^{1-\theta}
$$

It is proof that if there is available country $\mathrm{j}$ general utility- maximizing price index $\mathrm{Pj}$, quantity and variety of different goods produced $\mathrm{Nj}$ and its relative world size then it is likely to drive price of per unit output $\mathrm{Pi}$. As following:

$$
N_{i j}=\left(\frac{t_{i j}}{P_{i} P_{j}}\right)^{1-\theta} \frac{M_{i} M_{j}}{M_{w}} \text { Likewise } N_{j i}=\left(\frac{t_{i j}}{P_{i} P_{j}}\right)^{1-\theta} \frac{M_{i} M_{j}}{M_{w}}
$$

Given that $t_{i j}=t_{j i}=N_{i j}=N_{j i}$ it means it is also equal to $T_{i j}$ and $T_{i j}=$ bilateral trade follow. As last equation showing that, the impact of trade depend on $\theta$, which is representing the elasticity of intra temporal substitution.

\subsection{Model Specification}

The gravity model of trade depends on the balance of the forces in between the trading economies. Its stochastic specification is mentioned as following

$$
\begin{aligned}
& \ln \left(\operatorname{IMPORT}_{i j t}\right)=\alpha_{0}+\beta_{1} \ln \left(\operatorname{PCGDP}_{i t}\right)+\beta_{2} \ln \left(\operatorname{PCGDP}_{j t}\right)+ \\
& \beta 3 \ln \left(C P I_{i t}\right)+\beta_{4} \ln \left(C P I_{j t}\right)+\beta_{5} \ln \left(T R / G D P_{i t}\right)+\beta_{6} \ln \left(T R / G D P_{j t}\right) \\
& +\beta_{7} \ln \left(I N S_{i t}\right)+\beta_{8} \ln \left(I N S_{i j}\right)+\beta_{9} \ln \left(E R_{i t}\right)+\beta_{10} \ln \left(E R_{j t}\right)+\varepsilon_{i j t}
\end{aligned}
$$

Where the variables are as below

$\begin{array}{ll}\text { Import }_{i j t} & =\text { Total import of Malaysia (country i) from other OIC countries(country } \mathrm{j} \text { ) (in million USD) } \\ \mathrm{PCGDP}_{i t} & =\text { Per capita GDP of Malaysia } \\ \mathrm{PCGDP}_{j t} & =\text { Per capita GDP of country } \mathrm{j} \\ \mathrm{TR}_{\mathrm{GDP}} & =\text { Trade GDP ratio of Malaysia } \\ \mathrm{TR}_{\mathrm{it}} \mathrm{GDP}_{\mathrm{jt}} & =\text { Trade GDP ratio of country } \mathrm{j} \\ \mathrm{INS}_{i t} & =\text { Corruption perception index of Malaysia } \\ \mathrm{INS}_{j t} & =\text { Corruption perception index of country j } \\ \mathrm{CPI}_{i t} & =\text { Consumer Price Index of Malaysia } \\ \mathrm{CPI}_{j t} & =\text { Consumer Price Index of country } \mathrm{j} \\ \mathrm{ER}_{i t} & =\text { Real Exchange Rate of Malaysia } \\ \mathrm{ER}_{j t} & =\text { Real Exchange Rate of country } \mathrm{j}\end{array}$




\subsection{Data Sources}

All observations are based on annual data. The data used are in real terms. Data on Gross Domestic Product $(G D P), G D P$ per capita, foreign direct investments (FDIs), real exchange rates, total exports, total imports are obtained from the World Development Indicators (WDI) database of the World Bank and also from the International Financial Statistics (IFS), CD-ROM database and website of International Monetary Fund (IMF). Data on Malaysia's exports (country i export) to all other countries (country j's), Malaysia's imports (country i imports) from all other countries (country j's) are obtained from the Direction of trade statistics, CD-ROM database and website of International Monetary Fund (IMF).

Data on the distance (in kilometer) between Kuala Lumpur (capital of Malaysia) and other capital cities of country $\mathrm{j}$ are obtained from an Indonesian website: www.indo.com/distance. The data on Consumer Price Index (CPI) of all the Muslim countries are collected from the World Development Indicators (WDI) database of the World Bank and the Center of Advanced Research \& Studies of the Islamic Common Market website: www.carsicm.ir. For the measurement of the level of institutional quality, that is measured by the corruption index is obtained from the Corruption Perceptions Index (CPI) from Transparency International (TI) and retrieved from TI database at www.transparency.org/cpi.

\subsection{Method of Estimation}

Building on the econometric estimation of Gravity model, there are about 17 observations for each country from year 1995 to 2012, because of these long time series component these variables are expected to become function of their past. Considering variables becoming function of its past values it will consequently make residuals function of its past too, which by assumption of Ordinary Least Square will cause regression result to be invalid.

$$
\begin{aligned}
\ln \left(\text { Import }_{i j t}\right) & =f\left(\ln \left(\text { Import }_{i j t-1}\right)\right) \\
\varepsilon_{i t} & =f\left(\varepsilon_{i t-1}\right)
\end{aligned}
$$

So first step in the estimation process in to find out for all the variables in the model of they are function of their past or not. The econometric method used for this purpose is Unit Root tests. Recently, there are several studies utilized gravity model such as Abidin et al. (2014), Abidin et al. (2015) and Abidin and Haseeb (2015).

\subsubsection{Unit Root Test}

There are wide range of unit root test available in panel data now, this chapter will illustrate some of the unit root tests with its criteria to identify if the series in stationary (not a function of past) or non stationary (function of past). Numerous studies like Abidin et al. (2015), Bakar et al. (2014), Haseeb and Azam (2015) and Haseeb et al. (2015) used following panel unit root tests in their studies.

\section{IPS test [Im et al. (1997)]}

IPS test builds on the Time series ADF test on each country and then used the average for panel data, this is useful when all the cross sections (countries) are heterogeneous. Its specification is below.

$$
y_{i t}=\rho_{i} y_{i t-1}+\sum_{j=1}^{\rho_{i}} \varphi_{i t} \Delta y_{i t-j}+z_{i t}^{\prime} \gamma+\varepsilon_{i t}
$$

From this model it calculates average $t$ statistic

$$
\bar{t}=\frac{1}{N} \sum_{i=1}^{N} t_{\rho_{i}}
$$

If this $t$ statistic is significant then it means that at least one of the country is stationary, where as if it is insignificant then it will mean that all of the countries are non stationary.

\section{LLC Test [Levin, Lin \& Chu (2002)]}

LLC test standardizes the ADF test variable to make them free of autocorrelations. The difference in this model is that it assumes that all the cross sections (countries) are following common unit root process in other words all the countries have same type of relationship with its past.

$$
y_{i t}=\rho_{i} y_{i t-1}+z_{i t}^{\prime} \gamma+\mu_{i t}, i=1 \text { to } N, t=1 \text { to } T
$$

$\mathrm{H}_{0}: \rho=1$ (non stationary) $\mathrm{H}_{1}: \rho<1$ (stationary)

\section{Fisher type ADF and PP Test [Maddala and Wu (1999) and Choi (1999a)]}

This test uses non parametric (Chi-Square) approach in determining the stationarity of the series with added benefit of adoptability to non balanced panel data.

$$
y_{i t}=\rho_{i} y_{i t-1}+z_{i t}^{\prime} \gamma+\mu_{i t}, i=1 \text { to } N, t=1 \text { to } T
$$




$$
P=-2 \sum_{i=1}^{N} \ln \rho_{i}
$$

This $\mathrm{P}$ follows Chi Square distribution.

\subsubsection{Cointegration Test}

Since these unit root test are expected to indicate that all the included variables are non stationary I(1) which means that standard OLS estimation technique is not appropriate, here Kao (1999) proposed error correction based cointegration test which suggest that set of I(1) variables are found to be cointegrated (residuals become $\mathrm{I}(0))$ then the variables become long run related. For the following model of I(1) variables

$$
\begin{gathered}
y_{i t}=\mu_{i}+x_{i t}^{\prime} \beta+\mu_{i t}, i=1 \text { to } N, t=1 \text { to } T \\
\Delta \hat{\mu}_{i t}=\rho \hat{\mu}_{i t-1}+\sum_{j=1}^{p} \varphi_{j} \Delta \hat{\mu}_{i t-j}+v_{i t p}
\end{gathered}
$$

If $\mathrm{t}$ test applied on the $\rho$ coefficient found to be insignificant then the residuals are non stationary and there is no long run relation between the variables in the gravity model, where as if $\rho$ is significant it will mean that residuals are stationary and there is a long run relationship between the variables in the gravity model. This study follow studies such as Haseeb et al. (2014), Haseeb et al. (2014b) and Haseeb et al. (2015) for the cointegration.

\subsubsection{Long Run Model}

Since all the variables are proved to be cointegrated having long run relationship, this study will utilize FMOLS (Pedroni, 2000) model to estimate the long run coefficients. Following are the mathematical illustration of this FMOLS model. This model is made to estimate panel cointegrated coefficients.

$$
\begin{gathered}
y_{i t}=\alpha_{i}+\delta_{i}^{\prime} d_{i t}+x_{i t}^{\prime} \beta+u_{i t} \\
y_{i t}^{+}=y_{i t}-\sigma_{i, \varepsilon u}^{\prime} \sum_{i, \varepsilon \varepsilon}^{-1} \Delta x_{i t} \\
\hat{\beta}_{F M O L S}=\left[\sum_{i=1}^{N} \sum_{t=1}^{T} x_{i t} x_{i t}^{\prime}\right]^{-1}\left[\sum_{i=1}^{N} \sum_{t=1}^{T}\left(x_{i t} y_{i t}^{+}-\lambda_{i, \varepsilon u}\right)\right]
\end{gathered}
$$

\subsubsection{Short Run Model}

The residuals of the FMOLS model will be stored as ECM variable, which will be tested for presence of unit root. If the selected variables are found to be cointegrated then ECM variable will be expected to have no unit root (stationary) which is also confirmed via KAO cointegration test.

$$
\Delta y_{i t}=\alpha+\Delta x_{i t}^{\prime} \beta^{\prime \prime}-\gamma E C M_{t-1}+u_{i t}
$$

In this short run model if coefficient of lagged ECM is $-1<\gamma<0$ and significant then it will confirm that any disequilibrium in the long run cointegrating equilibrium model estimated by FMOLS is adjusted back towards the equilibrium through change in the dependent variable in the model which is TRADE $\mathrm{ij}_{\mathrm{j}}$. Here $\beta^{\prime \prime}$ will provide the short run effects of all the included independent variable in the dependent variable.

\section{Empirical Results}

In this section all the variables are tests for the presence of unit root using four tests (LLC, IPS, Fisher ADF and Fisher PPP) on level and first difference specification of the variable. A variable will be I(1) if it is non stationary (unit root present) in level specification and stationary (unit root is absent) in first difference.

Table 1. Unit root test results

\begin{tabular}{lllllc}
\hline $\begin{array}{l}\text { Panel A: Levin, Lin \& } \\
\text { Chu Test }\end{array}$ & Level & \multicolumn{1}{c}{$\begin{array}{c}\text { First } \\
\text { Difference }\end{array}$} & $\begin{array}{l}\text { Panel B: im, Pesaran \& } \\
\text { Shin W-Test }\end{array}$ & $\begin{array}{c}\text { Level } \\
\text { First } \\
\text { Difference }\end{array}$ & $\begin{array}{l}\text { W } \\
\text { Import }_{i j}\end{array}$ \\
$\mathrm{CPI}_{i}$ & 0.4152 & $0.000^{*}$ & $\mathrm{Import}_{i j}$ & 0.7504 & $0.000^{*}$ \\
$\mathrm{CPI}_{j}$ & $0.000^{*}$ & & $\mathrm{CPI}_{i}$ & 1.000 & $0.000^{*}$ \\
$\mathrm{ER}_{i}$ & 0.7966 & $0.000^{*}$ & $\mathrm{CPI}_{j}$ & 1.000 & $0.000^{*}$ \\
$\mathrm{ER}_{j}$ & 1.000 & $0.000^{*}$ & $\mathrm{ER}_{i}$ & 0.3216 & $0.000^{*}$ \\
$\mathrm{INS}_{i}$ & 0.9012 & $0.000^{*}$ & $\mathrm{ER}_{j}$ & 0.9812 & $0.000^{*}$ \\
$\mathrm{INS}_{j}$ & 0.5465 & $0.000^{*}$ & $\mathrm{INS}_{i}$ & 0.3320 & $0.000^{*}$ \\
$\mathrm{PCGDP}_{i}$ & 0.6608 & $0.000^{*}$ & $\mathrm{INS}_{j}$ & 0.6407 & $0.000^{*}$ \\
$\mathrm{PCGDP}_{j}$ & 1.000 & $0.000^{*}$ & $\mathrm{PCGDP}_{i}$ & 1.000 & $0.000^{*}$
\end{tabular}




\begin{tabular}{|c|c|c|c|c|c|}
\hline TradeGDP $_{i}$ & 1.000 & $0.000^{*}$ & TradeGDP $_{i}$ & 1.000 & $0.000^{*}$ \\
\hline TradeGDP $_{j}$ & 0.2348 & $0.000^{*}$ & TradeGDP $_{j}$ & 1.000 & $0.000^{*}$ \\
\hline Panel C: ADF Fisher & & & Panel D: PP Fisher Chi & & \\
\hline Chi Square & & & Square & & \\
\hline Import $_{i j}$ & 0.5273 & $0.000^{*}$ & Import $_{i j}$ & $0.0086^{*}$ & \\
\hline $\mathrm{CPI}_{i}$ & 1.000 & $0.000^{*}$ & $\mathrm{CPI}_{i}$ & 1.000 & $0.000^{*}$ \\
\hline $\mathrm{CPI}_{j}$ & 0.4925 & $0.000^{*}$ & $\mathrm{CPI}_{j}$ & $0.0004^{*}$ & \\
\hline $\mathrm{ER}_{i}$ & 0.9995 & $0.000^{*}$ & $\mathrm{ER}_{i}$ & $0.000^{*}$ & \\
\hline $\mathrm{ER}_{j}$ & 0.9435 & $0.000^{*}$ & $\mathrm{ER}_{j}$ & 0.9686 & $0.000^{*}$ \\
\hline $\mathrm{INS}_{i}$ & 0.9811 & $0.000^{*}$ & $\mathrm{INS}_{i}$ & $0.000^{*}$ & \\
\hline $\mathrm{INS}_{j}$ & 0.8992 & $0.000^{*}$ & $\mathrm{INS}_{j}$ & $1.0015^{*}$ & \\
\hline $\operatorname{PCGDP}_{i}$ & 1.000 & $0.000^{*}$ & $\mathrm{PCGDP}_{i}$ & 1.000 & $0.000 *$ \\
\hline PCGDP $_{j}$ & 1.000 & $0.000^{*}$ & $\mathrm{PCGDP}_{j}$ & 1.000 & $0.000 *$ \\
\hline TradeGDP $_{i}$ & 1.000 & $0.000^{*}$ & TradeGDP $_{i}$ & 1.000 & $0.000^{*}$ \\
\hline TradeGDP $_{j}$ & 0.4005 & $0.000 *$ & TradeGDP $_{j}$ & 0.4558 & $0.000^{*}$ \\
\hline
\end{tabular}

Note:*denoted statistically significant at $5 \%$ level

The results presented in Table1 shows that all the variables are non-stationary at level $\mathrm{I}(0)$ and become stationary at first difference $\mathrm{I}(1)$ on the basis of majority in four unit root tests. This confirms that standard panel data models like Pooled OLS, Fixed effect and Random effect models are in appropriate. Hence this study will proceed towards appropriate model which can incorporate $\mathrm{I}(1)$ variables.

Now the set of I(1) variable will only provide meaningful outcome if they are cointegrating. The results reported inTable2 of ADF Kao cointegration test on the residuals show significance evidence for presence of cointegration among the chosen variables in gravity model, this represent that Gravity model exists between Malaysia and selected OIC countries.

Table 2. Results of Kao's residual cointegration

\begin{tabular}{ccc}
\hline Test & $t$-Statistic & P-Value \\
\hline ADF & 4.128199 & $0.000^{*}$ \\
\hline
\end{tabular}

Note:*denoted statistically significant at $5 \%$ level

Presence of cointegration using KAO test provides evidence that following results from FMOLS model will not be spurious and this FMOLS model can be used to estimate Long run coefficients of the model. The results present in Table 3 shows that $\mathrm{ER}_{i}$ and $\mathrm{ER}_{\mathrm{j}}$ are significantly and positively affecting in expansion of import between Malaysia and OIC countries where as indicators like $\mathrm{CPI}_{j}$ and $\mathrm{PCGDP}_{i}$ are significantly and negatively effecting in contraction of trade between Malaysia and OIC countries. R square statistic represent that $91 \%$ of the variation in the import between Malaysia and OIC countries is explained by the independent variables selected as per Gravity model of international trade which is a significant portion of trade. 
Table 3. FMOLS test (dependent variable LNIMPORT $_{\text {IJ }}$ )

\begin{tabular}{ccccc}
\hline Variables & Coefficient & Std. Error & $\boldsymbol{t}$-Value & $\boldsymbol{P}$-Value \\
\hline $\mathrm{CPI}_{i}$ & 5.82 & 9.46 & 0.61 & 0.53 \\
$\mathrm{CPI}_{j}$ & -0.42 & 0.06 & -1.40 & $0.006^{*}$ \\
$\mathrm{ER}_{i}$ & $\mathbf{0 . 6 1}$ & 0.04 & 10.01 & $0.001^{*}$ \\
$\mathrm{ER}_{j}$ & $\mathbf{1 . 3 1}$ & 0.15 & 9.09 & $0.006^{*}$ \\
$\mathrm{INS}_{i}$ & -2.84 & 3.58 & -0.79 & 0.42 \\
$\mathrm{INS}_{j}$ & -0.42 & 1.06 & -0.40 & 0.68 \\
$\mathrm{PCGDP}_{i}$ & $\mathbf{- 1 . 6 2}$ & 0.07 & -24.68 & $0.03^{*}$ \\
$\mathrm{PCGDP}_{j}$ & 0.34 & 0.91 & 0.37 & 0.70 \\
$\operatorname{TradeGDP}_{i}$ & -0.07 & 1.38 & -0.05 & 0.95 \\
$\operatorname{TradeGDP}_{j}$ & -1.06 & 4.19 & -0.25 & 0.79 \\
& & & 0.91 & \\
\hline
\end{tabular}

Note:*denoted statistically significant at $5 \%$ level

Since Gravity model is providing us a hypothetical framework of how trade behaves hence if this model is valid than it should form equilibrium model which requires the residuals (for example disequilibrium) to be stationary with zero mean and constant variance (mathematically zero).

Table 4 below provides another confirmation regarding presence of cointegration as the residuals generated from the FMOLS are proved to be stationary using LLC, Fisher ADF and Fisher PP test.

Table 4. Results of ECM residual

\begin{tabular}{lcccc}
\hline \multirow{2}{*}{\multicolumn{1}{c}{ Test }} & \multicolumn{2}{c}{ LEVEL } & \multicolumn{2}{c}{ FIRST DIFFERENCE } \\
\cline { 2 - 5 } & t-statistics & p-values & t-statistic & p-value \\
\hline Levin, Lin \& Chu Test & -17.72 & 0.000 & -8.86 & $0.000^{*}$ \\
ADF Fisher Chi Square & 262.37 & 0.000 & 130.49 & $0.000^{*}$ \\
PP Fisher Chi Square & 283.84 & 0.000 & 128.91 & $0.000^{*}$ \\
\hline
\end{tabular}

Note:*denoted statistically significant at $5 \%$ level

Table 5 represent the short run component of Gravity model, here ECM(-1) is an important indicator for the performance of the model it should be between -1 and 0 and significant in order to show convergence towards equilibrium in the model. Here the coefficient of $\operatorname{ECM}(-1)$ is -0.35 and it is significant at $5 \%$ which means that if there is any disequilibrium (Note 1) then there will be $35 \%$ adjustment toward equilibrium each time period (Note 2). 
Table 5. Results of panel ECM (dependent variable $\triangle$ LNIMPORT $_{\text {IJ }}$ )

\begin{tabular}{|c|c|c|c|c|}
\hline Variables & Coefficient & Std. Error & $t$-Value & $P$-Value \\
\hline DLNCPI $_{i}$ & 5.97 & 7.87 & 0.75 & 0.45 \\
\hline $\operatorname{DLNCPI}_{j}$ & 0.61 & 1.93 & 0.31 & 0.75 \\
\hline DLNER $_{i}$ & 2.26 & 2.94 & 0.76 & 0.44 \\
\hline DLNER $_{j}$ & -1.05 & 0.96 & -1.09 & 0.27 \\
\hline DLNINS $_{i}$ & -2.40 & 1.44 & -1.66 & 0.10 \\
\hline DLNINS $_{j}$ & -0.37 & 0.47 & -0.77 & 0.43 \\
\hline DLNPCGDP $_{i}$ & -0.98 & 1.44 & -0.68 & 0.49 \\
\hline DLNPCGDP $_{j}$ & 1.85 & 1.02 & 1.80 & 0.07 \\
\hline DLNTradeGDP $_{i}$ & 0.26 & 1.84 & 0.14 & 0.88 \\
\hline DLNTradeGDP $_{j}$ & 0.09 & 0.79 & 0.12 & 0.90 \\
\hline ECM(-1) & -0.35 & 0.10 & -3.44 & 0.00 \\
\hline $\mathbf{C}$ & -0.08 & 0.22 & -0.36 & 0.71 \\
\hline \multicolumn{2}{|c|}{ R Square } & \multicolumn{3}{|c|}{0.23} \\
\hline \multicolumn{2}{|c|}{ DW Test } & \multicolumn{3}{|c|}{1.87} \\
\hline
\end{tabular}

Since the long run relation of the Gravity model is confirmed now Granger causality tests are applied which will identify the causality of individual variables. The results of Granger causality test are reported in Table6.

Table 6. Results of granger causality

\begin{tabular}{|c|c|c|c|c|}
\hline Direction of Causality & p-value & Lags & Decision & Outcome \\
\hline $\mathrm{LNINS}_{i} \rightarrow \mathrm{LNIMPORT}_{i j}$ & 0.0008 & 2 & Reject null & LNINS $_{i}$ does cause LNIMPORT $_{i j}$ \\
\hline LNIMPORT $_{i j} \rightarrow$ LNINS $_{i}$ & 0.5627 & 2 & Does not reject null & LNIMPORT $_{i j}$ does not cause LNINS $_{i}$ \\
\hline $\mathrm{LNINS}_{j} \rightarrow \mathrm{LNIMPORT}_{i j}$ & 0.0401 & 2 & Reject null & LNINS $_{j}$ does cause LNIMPORT $_{i j}$ \\
\hline LNIMPORT $_{i j} \rightarrow$ LNINS $_{j}$ & 0.0254 & 2 & Reject null & LNIMPORT $_{i j}$ does cause LNINS $_{j}$ \\
\hline LNPCGDP $_{i} \rightarrow$ LNIMPORT $_{i j}$ & 0.0232 & 2 & Reject null & LNPCGDP $_{i}$ does cause LNIMPORT $_{i j}$ \\
\hline LNIMPORT $_{i j} \rightarrow$ LNPCGDP $_{i}$ & 0.6279 & 2 & Does not reject null & LNIMPORT $_{i j}$ does not cause LNPCGDP $_{i}$ \\
\hline LNPCGDP $_{j} \rightarrow$ LNIMPORT $_{i j}$ & 0.005 & 2 & Reject null & LNPCGDP $_{j}$ does cause LNIMPORT $_{i j}$ \\
\hline LNIMPORT $_{i j} \rightarrow$ LNPCGDP $_{j}$ & 0.1249 & 2 & Does not reject null & LNIMPORT $_{i j}$ does not cause LNPCGDP $_{j}$ \\
\hline $\mathrm{LNER}_{i} \rightarrow \mathrm{LNIMPORT}_{i j}$ & 0.0158 & 2 & Reject null & $\mathrm{LNER}_{i}$ does cause $\mathrm{LNIMPORT}_{i j}$ \\
\hline $\mathrm{LNIMPORT}_{i j} \rightarrow \mathrm{LNER}_{i}$ & 0.6164 & 2 & Does not reject null & LNIMPORT $_{i j}$ does not cause LNER $_{i}$ \\
\hline $\mathrm{LNER}_{J} \longrightarrow \mathrm{LNIMPORT}_{i j}$ & 0.9501 & 2 & Does not reject null & $\mathrm{LNER}_{J}$ does not cause $\mathrm{LNIMPORT}_{i j}$ \\
\hline $\mathrm{LNIMPORT}_{i j} \rightarrow \mathrm{LNER}_{J}$ & 0.6540 & 2 & Does not reject null & LNIMPORT $_{i j}$ does not cause LNER $_{J}$ \\
\hline $\mathrm{LNCPI}_{i} \rightarrow \mathrm{LNIMPORT}_{i j}$ & 0.0170 & 2 & Reject null & $\mathrm{LNCPI}_{i}$ does cause $\mathrm{LNIMPORT}_{i j}$ \\
\hline LNIMPORT $_{i j} \rightarrow$ LNCPI $_{i}$ & 0.0448 & 2 & Reject null & $\mathrm{LNIMPORT}_{i j}$ does cause $\mathrm{LNCPI}_{i}$ \\
\hline $\mathrm{LNCPI}_{J} \longrightarrow \mathrm{LNIMPORT}_{i j}$ & 0.0928 & 2 & Does not reject null & $\mathrm{LNCPI}_{J}$ does not cause $\mathrm{LNIMPORT}_{i j}$ \\
\hline $\mathrm{LNIMPORT}_{i j} \rightarrow \mathrm{LNCPI}_{J}$ & 0.1088 & 2 & Does not reject null & LNIMPORT $_{i j}$ does not cause LNCPI $_{J}$ \\
\hline LNTRGDP $_{i} \rightarrow$ LNIMPORT $_{i j}$ & 0.2506 & 2 & Does not reject null & LNTRGDP $_{i}$ does not cause LNIMPORT $_{i j}$ \\
\hline LNIMPORT $_{i j} \rightarrow$ LNTRGDP $_{i}$ & 0.0008 & 2 & Reject null & LNIMPORT $_{i j}$ does cause LNTRGDP $_{i}$ \\
\hline LNTRGDP $_{J} \longrightarrow$ LNIMPORT $_{i j}$ & 0.3439 & 2 & Does not reject null & LNTRGDP $_{J}$ does not cause LNIMPORT $_{i j}$ \\
\hline LNIMPORT $_{i j} \rightarrow$ LNTRGDP $_{J}$ & 0.3511 & 2 & Does not reject null & LNIMPORT $_{i j}$ does not cause LNTRGDP ${ }_{J}$ \\
\hline
\end{tabular}


The decision based on the probability value confirmed that in case of independent variables, $\operatorname{INS}_{i}, \operatorname{INSj}, \mathrm{PCGDP}_{i}$, $\mathrm{PCGDP}_{j}, \mathrm{ER}_{i}$ and $\mathrm{CPI}_{i}$ reject the null hypothesis and these independent variables are Granger cause total import between Malaysia and OIC member countries.

\section{Concluding Remarks}

The aim of this paper is to investigate empirically on import relations between Malaysia and the OIC countries. Estimation of the Malaysia-OIC gravity model of import revealed that, among others real exchange rate of Malaysia and real exchange rate of OIC countries significantly and positively effect on Malaysia-OIC trade. While, per capita GDP of Malaysia and Consumer Price index of OIC countries are shows significant negative effect on Malaysia-OIC trade. Whereas, a better quality of institutions is proven to be crucial in enhancing Malaysia-OIC import relationship. These finding and results are important especially for policy makers in crafting policies to improve Malaysia-OIC import relationship in the future. In line with the empirical findings, it is crucial for Malaysian government to focus on accelerating the efforts to establish the Islamic Common Market (ICM), liberalizing the economy, further improving the strategic sectors such as the Islamic Banking and Finance, and intensify endeavors in curbing corrupt practice.

\section{References}

Abidin, I. S. Z., Bakar, N. A. A., \& Haseeb, M. (2015). Exploring Trade Relationship between Malaysia and the OIC Member Countries: A Panel Cointegration Approach (1995-2012). Asian Journal of Scientific Research, 8(1), 107. http://dx.doi.org/10.3923/ajsr.2015.107.121

Abidin, I. S. Z., \& Haseeb, M. (2015). Investigating Exports Performance between Malaysia and OIC Member Countries from 1997-2012. Asian Social Science, 11(7), p11.

Abidin, I. S. Z., Dan Jantan, M., Satar, N. M., \& Haseeb, M. (2014). Trade linkages between Malaysia and the OIC member countries: Empirical evidence based on gravity model. American Journal of Applied Sciences, 11(11), 1938-1944. http://dx.doi.org/10.3844/ajassp.2014.1938.1944

Abidin, I. S. Z., Haseeb, M., Azam, M., \& Islam, R. (2015). Foreign direct investment, financial Development, international trade and energy consumption: Panel data evidence from selected ASEAN Countries. International Journal of Energy Economics and Policy, 5(3), 841-850.

Abu Bakar, N. A., Haseeb, M., \& Azam, M. (2014).The Nexus between Education and Economic Growth in Malaysia: Cointegration and Toda-Yamamoto Causality Approach. Actual Problem of Economics, 12(162), 131-141.

Abu-Hussin, M. F. (2010). Exploring International Trade between Malaysia and GCC Countries: Empirical Analysis on Trends, Developments and Challenges. Unpublished Doctoral Thesis, Durham University: United Kingdom.

Al Atrash, H., \& Yousef, T. (2000). Intra-Arab Trade: is it too Little?. IMF Working Paper, 00/10, International Monetary Fund (IMF).

Anderson, J. E. (1979). A Theoretical Foundation for the Gravity Equation. American Economic Review, 69, 106-116.

Asmak, A. R., \& Abu-Hussin, M. F. (2009). GCC Economic Integration Challenge and Opportunity for Malaysian Economy. Journal of International Social Research, 2(9), 43-55.

Baltagi, B. H. (2005). Econometric Analysis of Panel Data (3rd ed.). New York: John Wiley \& Sons.

Bendjilali, B. (1997). An intra-trade Econometric model for OIC member Countries: A Cross Country Analysis. IRTI Research Papers, No. 55.

Bergstrand, J. (1985). The Gravity Equation in International Trade: Some Microeconomic Foundations and Empirical Evidence. Review of Economics and Statistics, 67, 474-481. http://dx.doi.org/10.2307/1925976

Dollar, D., \& Kraay, A. (2002). Institutions, Trade, and Growth. Journal of Monetary Economics, 50(1), 133-162. http://dx.doi.org/10.1016/S0304-3932(02)00206-4

Evelyn, S., Ahmad, Z., \& Thirunaukarasu, S. (2011). Leveraging Trade Opportunities with Non-Traditional Partners: The Malaysia-GCC Perspective. International Conference on International Trade and Investment: Globalisation at Crossroads - Implications for the Developing World, Le Meridien Hotel, Mauritius, 20-21 December.

Frankel, J. A., Stein E., \& Wei, S. (1995). Trading Blocs and the Americas: The Natural, the Unnatural, and the 
$\begin{array}{lllll}\text { Super-Natural. Journal of } & \text { Development }\end{array}$ http://dx.doi.org/10.1016/0304-3878(95)00005-4

Ghani, G. M. (2007). Does OIC Membership Reduce Trade? Journal of Economic Cooperation, 28(4), 39-62.

Hassan, M. K. (1998). An Empirical Investigation of Economic Cooperation among the OIC Member Countries. Economic Research Forum.

Haseeb, M., Bakar, N. A., Azam, M., Hassan, S., \& Hartani, N. H. (2014). The Macroeconomic Impact of Defense Expenditure on Economic Growth of Pakistan: An Econometric Approach. Asian Social Science, 10(4), 203-213. http://dx.doi.org/10.5539/ass.v10n4p203

Haseeb, M., Hartani, N. H., Bakar, N. A., Azam, M., \& Hassan, S. (2014). Exports, foreign direct investment and economic growth: Evidence from Malaysia (1971- 2013). American Journal of Applied Science, 11(6), 1010-1015. http://dx.doi.org/10.3844/ajassp.2014.1010.1015

Haseeb, M., \& Hartani, N. H. (2015). The Nexus between Female Labour Force Participation (FLFP) and Fertility rate in Selected ASEAN Countries: Panel Cointegration Approach. Modern Applied Science, 9(8), p29. http://dx.doi.org/10.5539/mas.v9n8p29

Haseeb, M., \& Azam, M. (2015). Energy Consumption, Economic Growth and $\mathrm{CO}_{2}$ Emission Nexus in Pakistan. Asian Journal of Applied Sciences, 8, 27-36. http://dx.doi.org/10.3923/ajaps.2015.27.36

IMF \& Dinar Standard. (2008). Retrieved July 11, 2010, from http://www.dinarstandard.com/intraoic/intraoic052708.html

Ismail, N. (2008). Explaining Malaysian Bilateral Trade Using the Gravity Model. The Empirical Economic Letters, 7(8), 811-818.

Khalifah, N. A. (1993). The Structure of Intra-Muslim Countries Trade. Malaysian Economic Journal, 27, 57-84.

Levchenko, A. (2004). Institutional Quality and International Trade. IMF Working Paper 04/231. http://dx.doi.org/10.5089/9781451875560.001

Maddala, G. S. (2001). Introduction to Econometrics (3rd ed.). New York: John Wiley \& Sons.

Malaysian Ministry of International Trade and Industry. (2009). MITI Annual Report 2008, Kuala Lumpur, Malaysia.

Nuroglu, E., \& Dreca, N. (2011). Analyzing Bilateral Trade Flows of Bosnia and Herzegovina Under the Framework of Gravity Model. Journal of Business and economics, 3(1), 30-50.

Poyhonen, P. (1963). A Tentative Model for the Volume of Trade between Countries. Welwirtschaftliches Archiv, 90, 93-99.

Rahman, M. M. (2003). A Panel Data Analysis of Bangladesh's Trade: The Gravity Model Approach. Unpublished Doctoral Dissertation, University of Sydney: Australia.

Rahman, M. M. (2009). Australia's Global Trade Potential: Evidence from the Gravity Model Analysis. Oxford Business \& Economics Conference, 24-26 Jun, Oxford University: United Kingdom.

Raimi, L., \& Mobolaji, H. I. (2008). Imperative of Economic Integration Among Muslim Countries: Lessons $\begin{array}{llll}\text { From } \quad \text { European } \quad \text { Globalisation. } & \text { Humanomics, }\end{array}$ http://dx.doi.org/10.1108/08288660810876840

Reilly, W. J. (1931). The Law of Retail Gravitation. New York: Pillsbury Publishers.

Sharma, S. C., \& Chua, S. Y. (2000). ASEAN: Economic Integration and Intra-Regional Trade. Applied Economics Letters, 7(3), 165-169. http://dx.doi.org/10.1080/135048500351726

Stewart, J. Q. (1948). Demographic Gravitation: Evidence and Application. Sociometry, 11(1), 31-58. http://dx.doi.org/10.2307/2785468

Summary, R. (1989). A Political-Economic Model of U.S. Bilateral Trade. The Review of Economics and Statistics, 71(1), 179-182. http://dx.doi.org/10.2307/1928068

Tinbergern, J. (1962). Shaping the World Economy: Suggestions for an International Economic Policy. Journal of Farm Economics, 46(1), 271-283. 


\section{Notes}

Note 1. deviation in import which is not explained by the model.

Note 2. adjustment is usually performed using the dependent variable.

\section{Copyrights}

Copyright for this article is retained by the author(s), with first publication rights granted to the journal.

This is an open-access article distributed under the terms and conditions of the Creative Commons Attribution license (http://creativecommons.org/licenses/by/3.0/). 